\title{
A Study About Brand Preference of Washing Machine with Reference to Rural Area of Palanpur Taluka
}

\author{
S. A. Parbadiya M.Com, B.Ed., M.Phil \\ Ph.D. Research Scholar, Hemchandracharya North Gujarat University, Patan, Gujarat, India
}

\begin{abstract}
Washing machine is one of the widely used home equipment which used to wash the cloths. India is one of the fast developing countries in the world. At present it is the need to work both in the family. Therefore to simplify the washing work, the people need machine for washing. In washing machines number of varieties is there. Indian rural consumers today not only have a wide variety of brands to choose from, but also the option to buy a machine that is just right for them from amongst the several models available. Apart from these factors that they should consider the various wash programs, the wash mechanism and some convenience features that their machine should have in order to provide the maximum level of comfort.
\end{abstract}

With this back draft, this article makes an attempt to analyze the brand reference, factor effecting on brand preference of washing machines.

Key Words: Washing Machine, Brand preference, factor effecting on brand preference

\section{INTRODUCTION}

"Yesterday's luxurious are today's necessaries". Household durable goods which were once considered luxury items have become a necessity because of the changing lifestyle, rising income levels, easy availability of finance, increase in consumer awareness and introduction of new models. So the demand for consumer household durable goods has increased significantly. Household durable goods like washing machine, air conditioner, microwave oven, television and refrigerator are no longer considered luxury items. Household durable goods in India are one of the fast growing and competitive industries of the country. The growth of this industry is really attributed to the most distinct feature of Indian economy-population explosion.
Every manufacturer is trying to make their products more popular and thereby try to be successful. But all the manufacturers do not attain success due to several reasons. One of the most important reasons is consumers behaviour. It is very difficult to predict and understand this obviously, it becomes important for every business to concentrate on consumers and their behaviour.

The primary work of the manufacturers in the olden days was to concentrate only in the production areas. But the trend today is totally different as the importance on marketing the business will never be successful. Rural market is the key to survival in India. It is a fact that rural market in India is the largest potential market. Rural people in consumption patterns have increased and their Life styles and attitudes have changed. The marketing programmes and policies depends upon the consumers' perception will facilitate the marketer in determining the size, form, style, colour, package brand etc. All psychological, social and physical behaviour ofpotential consumers as they become aware of evaluate, purchase, consumer and tell others about product and services.

A very important aspect of the purchase process is the actual activity of making the purchase, which actually goes shopping are something that reveals the aspects of consumer behavior and perception. This study aims to focus specially on rural consumers' brand preference towards washing machine.

\section{STATEMENT OF THE PROBLEM}

In recent years, the lifestyle of a large number of rural consumers in India has changed dramatically and the process of change is on. The buying behavior of the rural consumers is influenced by several factors such as socio-economic conditions, cultural environment, 
literacy level, occupation, geographical location, efforts on the part of sellers, exposure to media etc.

In olden days, people engaged the services of washerman to wash their dresses. But technological advancement has introduced new means. The introduction of washing machine has simplified the task of washing dresses. Usually washing their cloths themselves helps in better maintenance of the clothes. But people have no time to wash their dresses in the modern world. Now-a-days people are busy round the clock. So they prefer a machine to wash in order to spend that time either to rest or to earn. It also has turned out to be a safer way of washing. The manufacturers of different brands of washing machine project varying features of their products. The consumers are not in a position to identify the good brand. They are finding it very difficult to select a right brand. So many consumers are ready to buy any brand recommended by other consumers. Thus, all these household goods make life more comfortable, easier and happier. The scenario in the household durable goods industry is equally challenging. The leading companies like Samsung, Videocon, Sony, LG and others by introducing brands at various price points have effectively segmented the market which has resulted in faster market expansion and A very important aspect of the study about brand preference of rural consumer. This study aims to focus on rural consumers' brand preference towards Washing machine.

\section{SIGNIFICANCE OF THE STUDY}

The manufacturers of different brands of washing machine project varying features of products. The consumers are not in a position to identify the good brand. They are finding it very difficult to select a right brand. At that time, some of the consumers are ready to buy any brand recommended by another consumer. Some customers are not to change their behaviour and also their brand preference. These kinds of consumers with brand loyalty are ready to wait for their favored brand, if it is not available in the market. In this critical situation, some manufacturers are producing washing machines by means of technological advancement. They are giving a wide publicity to their product and try to withstand the competition. Consumers must give at most care while purchasing these household durable goods because of its high cost and infrequent purchase. In addition to this they must have good choosing capacity due to the availability of multiple or various brands in the market. So it is significant for the preferences of rural consumers towards washing machine.

The exact logic for the purchase of a particular washing machine is highly an uncertain factor. Hence, the researcher takes up this study to deal with the behaviour about beyond preference of washing machine users.

\section{SCOPE OF THE STUDY}

In the modern age there are plenty of household durable goods like electric fan, mixer grinder, washing machine, refrigerator, air conditioner, furniture etc. to make our life more comfortable and easier. But the researcher has confined the study only washing machine users. point of view and covers rural area of palanpur taluka.

As household durable goods occupy an important position in the modern life, an attempt is made to find out the brand preference of rural consumers. This study helps to understand the factors, which influence the rural consumers to purchase the washing machine.

\section{REVIEW OF LITERATURE}

For the purpose of this study a lot of literature has been reviewed, that is, books, journals, magazines, newspapers, thesis etc. Some of the reviewed literature has been discussed below:

D Janaki, P and Shanthi, $P$ (2013) in their study entitled, "Marketing Stimuli in Purchase of Home Appliances From Customer Perspectives", The findings of the study included that education and income of the respondents are the two socioeconomic variables which have significant association in all the stages which the buyers undergo while purchasing home appliances.

Shahram Jenabi, Seyed Yahya Seyed Danesh and Minoo Yousefi (2013) made a study titled, "Examining the effect of Brand dimension (trademark) on home appliances consumers' behavior Case study: LG brand in Rasht city", Results showed that aspects of brand's dimensions have a positive effect on consumers' behavior and there is significant relationship between these two components. Thus, it is suggested to LG brand to use its competitive advantage, particularly its reputation, identity and brand management, and other aspects of brand (mentioned in this research) to lead its consumers' behavior to a positive direction. 
$>$ Kalaiselvi and Muruganandam (2013) made a study on, "Consumer Attitude towards Promotional Schemes and Influence of Brand on Purchasing Home Appliances", The results indicate that whatever attractive promotional schemes may be, "brand name" plays a dominant role in purchasing the home appliances. Maximum of the respondents have interest in some of the promotional schemes such as price discount, exchange scheme, warranty, etc. It is concluded that whatever attractive promotional schemes may be, "brand name" plays a dominant role in purchasing the home appliances. Maximum of the respondents have interest in some of the promotional schemes such as price discount, exchange scheme, warranty, etc. and also consumers prefer price discount as first, when compared to non- price schemes. Most of the consumers in Erode city, Tamilnadu, India have replaced their home appliances at Exchange offer period and also they are satisfied with the home appliances, purchased at the time of offer period.

$>$ Dr. M. Selvakumae, K. Jegatheesan (2012) made a study on "Brand Preference : A study with Reference To Washing Machine", cin Shivakashi. The findings of the study In the next generation, the technological advancement has got its effect on different field. It is well understood from this study that, customers are highly motivated by TV advertisements, in getting product awareness. The standard of living of the people of a country is measured by the products they use and consume. In this respect, washing machine which has become an important consumer durable product in the Indian households, tells us of the improvement of standard of living.

\section{OBJECTIVES OF THE STUDY}

The objectives of the study are as follows:

$>$ To know the Demographic profile of washing machines users.

$>$ To understand the behaviour of the consumer's, in case of Non-availability of their favorite brand.

$>$ To determine the consumer's brand preference of washing machine.

$>$ To know the factor affecting on brand preference of washing machines in rural area.

$>$ To gives suitable suggestions on the basis of the findings of the study.

\section{RESEARCH METHODOLOGY}

The present study is an empirical research and it is based on the survey method. This study is descriptive and analytical in nature based on primary and secondary data.

\section{$>$ Data Collection}

Primary data have been collected from the respondents by using a well structured, non-disguised questionnaire. Secondary data for the study were collected from books, journals, research articles, magazines, reports, newspapers and websites.

\section{Sampling size and design}

Total rural area of Palanpur taluka will be identifying as population of this study.

Simple random sampling method was employed to select the sample respondents. Respondents were chosen whichever use washing machine from five villages of Palanpur taluka in the study. a sample size of 250 was considered as reasonable. Hence, selecting 50 respondents from each village. totally 250 respondents were selected randomly from five villages of Palanpur taluka are below:

Table - 1 Village wise classification of sample respondents

\begin{tabular}{|c|c|c|}
\hline Sr. No. & Name of Village & Respondents \\
\hline en 1 & Sejalpura & 50 \\
\hline 2 & Badargadh & 50 \\
\hline 3 & Mervada & 50 \\
\hline 4 & Lalavada & 50 \\
\hline & Total & $\mathbf{2 5 0}$ \\
\hline
\end{tabular}

\section{Analysis of Data}

The primary data collected from the consumers will be analyzed by using MS EXCEL to obtain the results concerning the objectives of the study. Percentages method applied for analyzing the responses of rural consumers of Palanpur Taluka.

\section{ANALYSIS AND INTERPRETATION}

In this section presented demographic Profile and opinion of the Sample Respondents with select criteria and also Analysis and interpretation data with use of table and percentage.

The study has examined the age, sex, educational status, occupation and monthly income of the family and also possession of brand, factor affecting on brand preference and opinion about when non availability of favorite brand of the respondents. 
International Journal of Trend in Scientific Research and Development (IJTSRD) ISSN: 2456-6470

The following tables shows the Demographic classification and opinion of the respondents.

TABLE - 2 GENDER WISE CLASSIFICATION

\begin{tabular}{|c|c|c|c|}
\hline $\begin{array}{c}\text { Sr.. } \\
\text { No. }\end{array}$ & Gender & $\begin{array}{c}\text { Number of } \\
\text { Respondents }\end{array}$ & Percentage \\
\hline 1 & Male & 165 & 66 \\
\hline 2 & Female & 85 & 34 \\
\hline & Total & $\mathbf{2 5 0}$ & $\mathbf{1 0 0}$ \\
\hline
\end{tabular}

\section{Source: Primary data}

It can be observed from the above table that, Out of the total 250 sample rural consumer respondents, $66.00 \%$ are male whereas $34.00 \%$ are female. Thus, It can be seen that, the majority i.e. $66.00 \%$ of the sample rural consumer respondents are male.

\section{TABLE - 3 AGE WISE CLASSIFICATION}

\begin{tabular}{|c|c|c|c|}
\hline $\begin{array}{c}\text { Sr. } \\
\text { No. }\end{array}$ & Age (year) & $\begin{array}{c}\text { Number of } \\
\text { Respondents }\end{array}$ & Percentage \\
\hline 1 & Below 20 & 73 & 29.20 \\
\hline 2 & 20 to 30 & 105 & 42.00 \\
\hline 3 & 30 to 40 & 45 & 18.00 \\
\hline 4 & 40 to 50 & 15 & 06.00 \\
\hline 5 & Above 50 & 12 & 4.80 \\
\hline & Total & $\mathbf{2 5 0}$ & $\mathbf{1 0 0}$ \\
\hline
\end{tabular}

Source: Primary data

It can be observed from the above table that, Out of the total 250 sample rural consumer respondents, $42.00 \%$ are of the age group of 20 to 30 years, 29.20 $\%$ are of the age group of below 20 years, $18.00 \%$ are of the age group of 30 to 40 years, $6.00 \%$ are of the age group of 40 to 50 years and $4.80 \%$ are of the age group of above 50 years.

Thus, it can be seen that, the majority $42 \%$ of the sample rural consumer respondents are in the age group of 20 to 30 years.

\begin{tabular}{|c|c|c|c|}
\hline $\begin{array}{l}\text { Sr. } \\
\text { No }\end{array}$ & Education & $\begin{array}{l}\text { Number of } \\
\text { Respondents }\end{array}$ & Percentage \\
\hline 1 & Below SSC & 13 & 5.20 \\
\hline 2 & SSC & 20 & 8.00 \\
\hline 3 & HSC & 21 & 8.40 \\
\hline 4 & Graduate & 95 & 38.00 \\
\hline 5 & Post Graduate & 40 & 16.00 \\
\hline 6 & Professional & 21 & 8.40 \\
\hline 7 & $\begin{array}{l}\text { Technical/ } \\
\text { Diploma }\end{array}$ & 17 & 6.80 \\
\hline \multirow[t]{2}{*}{8} & Illiterate & 23 & 9.20 \\
\hline & Total & 250 & 100 \\
\hline
\end{tabular}

Source: Primary data
It can be observed from the above table that, Out of the total 250 sample rural consumer respondents,

$38.00 \%$ are Graduate, $16.00 \%$ are post-graduates, $9.20 \%$ are Illiterate, $8.40 \%$ are Professional and HSC , $8.00 \%$ are ssc, $6.80 \%$ are Technical/Diploma and $5.20 \%$ are Below SSC.

Thus, it can be seen that the majority i.e.38.00\% of the sample rural consumer respondents are graduates.

\section{TABLE - 5 OCCUPATIONAL STATUS}

\begin{tabular}{|c|c|c|c|}
\hline $\begin{array}{c}\text { Sr. } \\
\text { No. }\end{array}$ & Occupation & $\begin{array}{c}\text { Number of } \\
\text { Respondents }\end{array}$ & Percentage \\
\hline 1 & $\begin{array}{c}\text { Government } \\
\text { Service }\end{array}$ & 21 & 8.40 \\
\hline 2 & Private Service & 29 & 11.60 \\
\hline 3 & Own Business & 28 & 11.20 \\
\hline 4 & Agriculture & 122 & 48.80 \\
\hline 5 & Self Employed & 28 & 11.20 \\
\hline 6 & Labor & 03 & 01,20 \\
\hline 7 & Unemployed & 11 & 04.40 \\
\hline 8 & Student & 08 & 03.20 \\
\hline & Total & $\mathbf{2 5 0}$ & $\mathbf{1 0 0}$ \\
\hline
\end{tabular}

\section{Source: Primary data}

It can be observed from the above table that, Out of the total 250 sample rural consumer respondents, $48.80 \%$ are agriculturists, $11.60 \%$ are engaged in Private Service, $11.20 \%$ are engaged in business activity and self employed, $8.40 \%$ are engaged in government service, $4.40 \%$ are unemployed, $3.20 \%$ are student and $1.20 \%$ are labour.

Thus, it can be seen that, the majority $48.80 \%$ of the sample rural consumer respondents are agriculturists.

TABLE - 6 MONTHLY INCOME

\begin{tabular}{|c|l|c|c|}
\hline $\begin{array}{c}\text { Sr. } \\
\text { No. }\end{array}$ & $\begin{array}{c}\text { Monthly } \\
\text { income }\end{array}$ & $\begin{array}{c}\text { Number of } \\
\text { Respondents }\end{array}$ & Percentage \\
\hline 1 & $\begin{array}{l}\text { Below } \\
\text { Rs.5000 }\end{array}$ & 88 & 35.20 \\
\hline 2 & $\begin{array}{l}\text { Rs.5000 } \\
-15000\end{array}$ & 44 & 17.60 \\
\hline 3 & $\begin{array}{l}\text { Rs. } 15000 \\
-25000\end{array}$ & 78 & 31.20 \\
\hline 4 & $\begin{array}{l}\text { Rs.25000 } \\
-35000\end{array}$ & 22 & 08.80 \\
\hline 5 & $\begin{array}{l}\text { Rs.35000 } \\
-45000\end{array}$ & 13 & 05.20 \\
\hline 6 & $\begin{array}{l}\text { Above } \\
\text { Rs.45000 }\end{array}$ & 5 & 02.00 \\
\hline & Total & $\mathbf{2 5 0}$ & $\mathbf{1 0 0}$ \\
\hline
\end{tabular}

Source: Primary data 
International Journal of Trend in Scientific Research and Development (IJTSRD) ISSN: 2456-6470

It can be observed from the above table that, Out of the total 250 sample rural consumer respondents, $35.20 \%$ are below Rs. 5000, $31.20 \%$ are from the Rs.15000 to 25000 Income group, $17.60 \%$ are from the Rs.5000 to 15000 income group, $8.80 \%$ are from the Rs.25000 to 35000 income group, $5.20 \%$ are from the Rs.35000 to 45000 income group and $2.00 \%$ are of the above Rs.45000 Income Group.

Thus, it can be seen that, the majority i.e. $35.20 \%$ of the sample rural consumer respondents are from the Below Rs. 5000 Income Group.

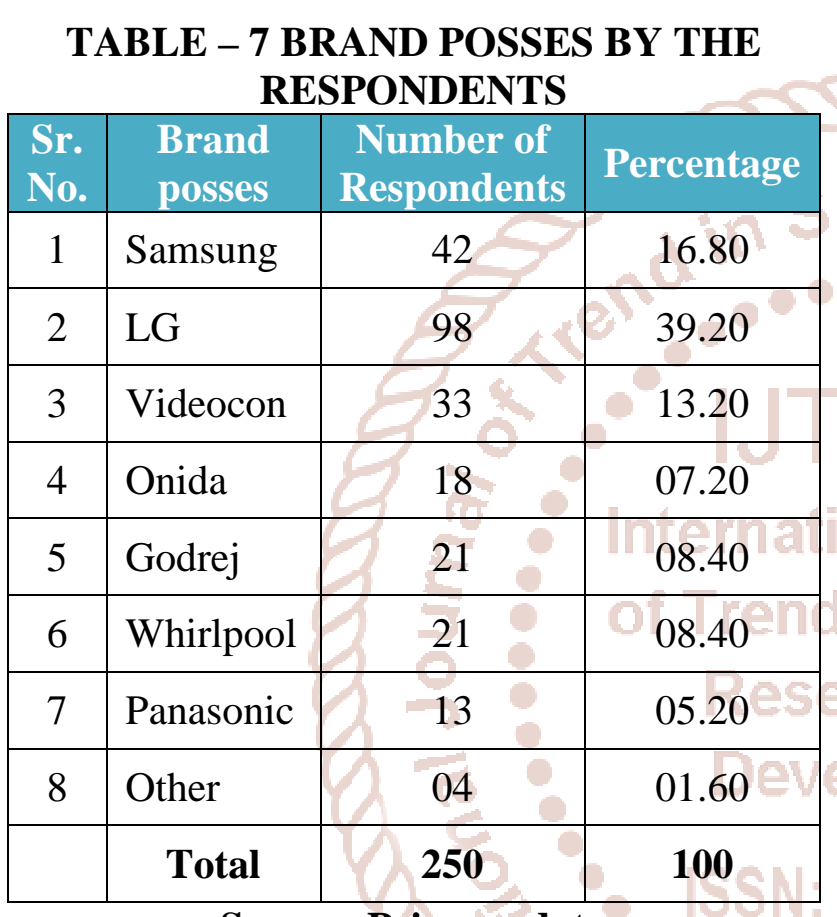

\section{Source: Primary data}

It can be observed from the above table that, Out of the total 250 sample rural consumer respondents, $39.20 \%$ of the rural consumers considered LG Washing machines, $16.80 \%$ considered Samsung brand, $13.20 \%$ are using Videocon , $8.40 \%$ preferred Whirlpool and Godrej , 7.20 \% are using Onida, 5.20 $\%$ are using Panasonic and only $1.60 \%$ are preferred other brand of Washing machine.

Thus, it can be seen that, the majority i.e.39.20\% of the sample rural consumer respondents are preferred LG washing machine.

\section{TABLE - 8 FACTOR AFFECTING ON BRAND PREFERENCE}

\begin{tabular}{|c|l|c|c|}
\hline $\begin{array}{c}\text { Sr. } \\
\text { No. }\end{array}$ & \multicolumn{1}{|c|}{ Factor } & $\begin{array}{c}\text { Number of } \\
\text { Respondents }\end{array}$ & Percentage \\
\hline 1 & Price & 63 & 25.20 \\
\hline 2 & Quality & 28 & 11.20 \\
\hline 3 & $\begin{array}{l}\text { Design \& } \\
\text { color }\end{array}$ & 12 & 04.80 \\
\hline 4 & $\begin{array}{l}\text { Warranty and } \\
\text { guaranty }\end{array}$ & 31 & 12.40 \\
\hline 5 & $\begin{array}{l}\text { After sales } \\
\text { service }\end{array}$ & 23 & 09.20 \\
\hline 6 & $\begin{array}{l}\text { Promotional } \\
\text { offer }\end{array}$ & 77 & 30.80 \\
\hline 7 & Durability & 09 & 03.60 \\
\hline 8 & Technology & 07 & 02.80 \\
\hline 7 & Total & $\mathbf{2 5 0}$ & $\mathbf{1 0 0}$ \\
\hline
\end{tabular}

\section{Source: Primary data}

It can be observed from the above table that, Out of the total 250 sample rural consumer respondents, Opinion about Influencing factor on brand preference, $30.80 \%$ respondents Says that promotional offer, $25.20 \%$ are says that price, $12.40 \%$ are says that Warranty and guaranty , $11.20 \%$ are says that quality, $9.20 \%$ are says that after sales service, $4.80 \%$ are says that design and color, $3.60 \%$ are says that durability and remaining $2.80 \%$ are says that technology is the affected on brand preference of washing machine.

Thus, it can be seen that, the majority i.e.30.80\% of the sample rural consumer respondents are believe that the most effective factor is promotional offer for purchasing to washing machine.

\section{TABLE - 9 NON AVAIBILITY OF FAVORITE BRAND}

\begin{tabular}{|c|l|c|c|}
\hline $\begin{array}{c}\text { Sr. } \\
\text { No }\end{array}$ & \multicolumn{1}{|c|}{ Opinion } & $\begin{array}{c}\text { Number of } \\
\text { Respondents }\end{array}$ & Percentage \\
\hline 1 & $\begin{array}{l}\text { Try at another } \\
\text { shop for same } \\
\text { brand }\end{array}$ & 32 & 12.80 \\
\hline 2 & $\begin{array}{l}\text { Postpone the } \\
\text { purchase }\end{array}$ & 23 & 09.20 \\
\hline 3 & $\begin{array}{l}\text { Drop the } \\
\text { purchase }\end{array}$ & 108 & 43.20 \\
\hline 4 & $\begin{array}{l}\text { Purchase another } \\
\text { available brand }\end{array}$ & 57 & 22.80 \\
\hline 5 & $\begin{array}{l}\text { Depend on trader } \\
\text { advise }\end{array}$ & $\mathbf{2 5 0}$ & $\mathbf{1 0 0}$ \\
\hline & \multicolumn{2}{|r|}{ Total } & \multicolumn{2}{|c|}{ Source } \\
\hline
\end{tabular}

Source: Primary data 
It can be observed from the above table that, Out of the total 250 sample rural consumer respondents, behaviuor in case of non availability of their favorite brand of washing machine, It is $43.20 \%$ are of the respondents Purchase another available brand, $22.80 \%$ are of the Depend on trader advise, $12.80 \%$ are of the try at another shop for same brand, $12.00 \%$ are of the Drop the purchase and remaining $9.20 \%$ are of the respondents postpone the purchase of washing machine.

Thus, it can be seen that, the majority i.e.43.20\% of the sample rural consumer respondents are Purchase another available brand in case of non-availability of their favorite brand of washing machine.

\section{FINDINGS}

From the study, it is found that the

$>$ the majority i.e $66.00 \%$ of the sample rural consumer respondents are male.

$>$ the majority i.e. $42 \%$ of the sample rural consumer respondents are from the age group of 20 to 30 years.

$>$ the majority i.e. $38.00 \%$ of the sample rural consumer respondents are graduates.

$>$ the majority i.e. $48.80 \%$ of the sample rural consumer respondents are agriculturists.

$>$ the majority i.e. $35.20 \%$ of the sample rural consumer respondents are from the Below Rs. 5000 Income Group.

$>$ the majority i.e. $39.20 \%$ of the sample rural consumer respondents are preferred LG washing machine.

$>$ the majority i.e. $30.80 \%$ of the sample rural consumer respondents are believe that the most effective factor is promotional offer for purchasing to washing machine.

$>$ the majority i.e. $43.20 \%$ of the sample rural consumer respondents are Purchase another available brand in case of non-availability of their favorite brand of washing machine.

\section{SUGGESTIONS}

$>$ In the study, promotional offer is the top most factors Influencing on the brand preference of purchasing washing machines. Therefore, marketers should formulate their marketing strategies with due consideration for these factor.

$>$ The Majority of respondents are Purchase another available brand in case of non-availability of their favorite brand of washing machine. The manufacturers can take good measures to distribute their brands in all places of Palanpur taluka and in particularly to distribute their brand in rural areas.

It was found that the majority of the sample rural consumer respondents are from the Below Rs. 5000 Income Group. Hence, it is suggested that proper steps could be taken by the manufacturer to reduce the prices of washing machine. If they do so, it can be expected that more number of lower class people may come forward to buy more products. Turnover of washing machine may be increased.

Majority of the sample respondents preferred LG washing machine. So the manufacturers must try their level best to keep up their reputation.

\section{CONCLUSION}

Consumer behaviour consists of all human behaviour which reflects in making purchase decisions. An understanding of the consumer behaviour enables a marketer to take marketing decisions which are compatible with its consumer needs. One of the most important areas for marketers to understand in planning their strategies is how families reach their purchase decisions. The present study highlights the various factors affecting on brand preference and the consumer behaviour towards the brand preference of washing machine in rural area of palanpur taluka. The findings of the study will enable the marketers to lay an emphasis on an effective marketing of products.

\section{REFERENCES}

1. Philip Kotler, Marketing Management, PracticeHall of India Private Limited, New Delhi, 1997.

2. T. Jesi (2017), “A Study on Consumer Perception on Rural Consumer Toward Household Durable Goods in Thoothukudi District", Unpublished ph.d. Thesis Submitted to Manonmaniam Sundarnar University Tirunelveli, Tamilnadu.

3. A. Abdul Brosekhan, (2016) "A Study on Consumer Behavior Toward Household Appliances in Ramanathapuram" , unpublished ph.d. Thesis Submitted to Manonmaniam Sundarnar University Tirunelveli, Tamilnadu.

4. Janaki, P and Shanthi, P (2013) "Marketing Stimuli In Purchase Of Home Appliances From Customer Perspectives", International Journal of Sales \& Marketing Management Research and Development (IJSMMRD), Vol. 3, Issue 2, pp. 23-30. 
International Journal of Trend in Scientific Research and Development (IJTSRD) ISSN: 2456-6470

5. Shahram Jenabi, Seyed Yahya Seyed Danesh and Minoo Yousefi (2013) "Examining the effect of Brand dimension (trademark) on home appliances consumers' behavior Case study: LG brand in Rasht city", International Research Journal of Applied and Basic Sciences, Vol.4, Issue.7, pp.1894-1900.

6. Kalaiselvi, K.T and Muruganandam, D (2013) "Consumer Attitude Towards Promotional Schemes and Influence of Brand On Purchasing
Home Appliances", International Journal Of Scientific Research, Vol.2, Issue. 6, pp.337-339.

7. Dr. M. Selvakumae, K. Jegatheesan (2012 ) “ Brand Preference : A study with Reference To Washing Machine", Asian Journal of Research in Marketing, Vol. 1, Issue 5,

8. http://www.aijsh.org

9. https://www. Researchgate.net/publication

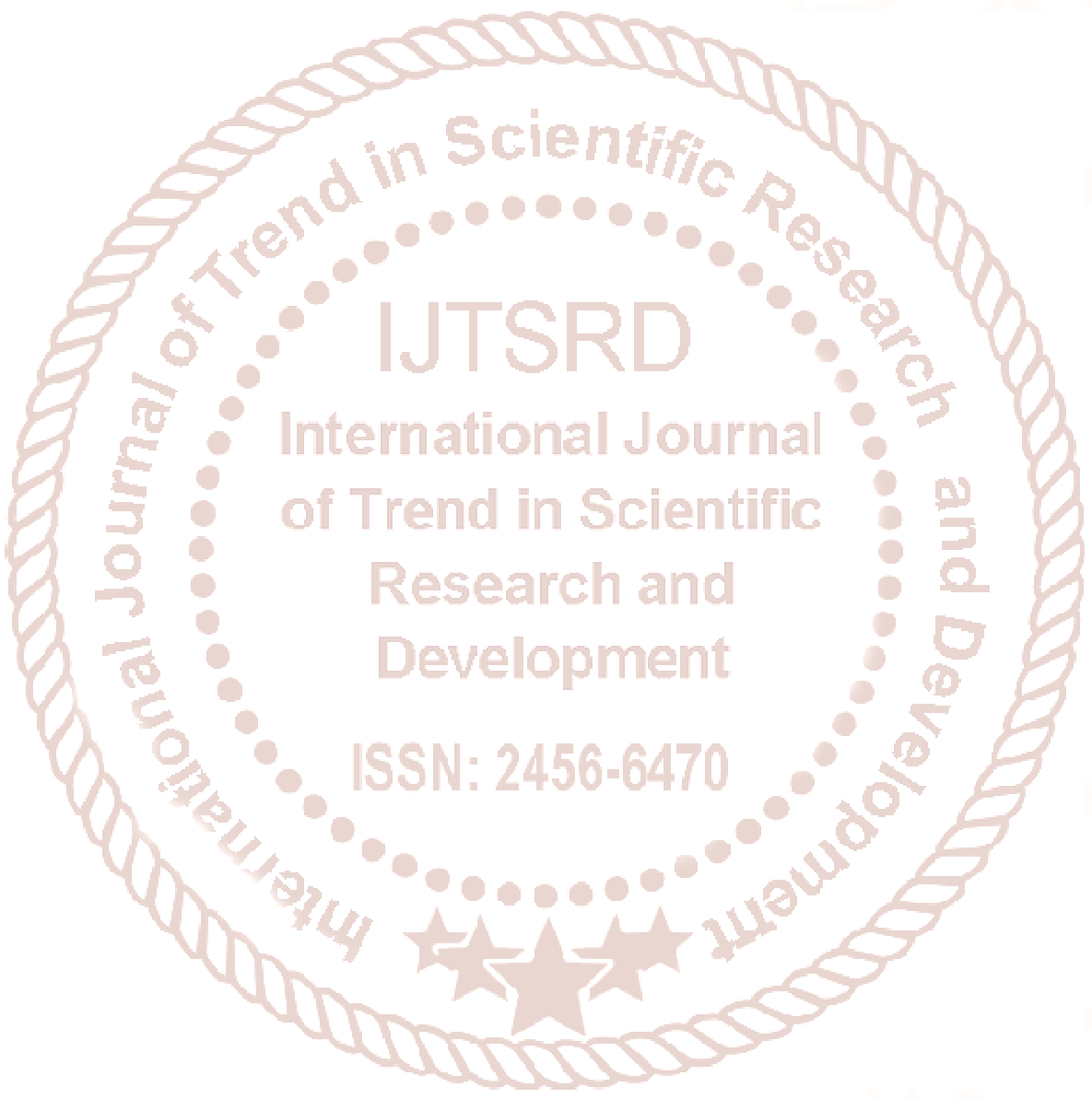

